\title{
Coupling between sediment biogeochemistry and phytoplankton dynamics in anthropised freshwater marshes of Charente Maritime, France
}

\author{
RAPHAËL MONCELON ${ }^{1}$, CHRISTINE DUPUY ${ }^{1}$, PHILIPPE \\ PINEAU $^{1}$, ERIC BÉNÉTEAU ${ }^{2}$, OLIVIER PHILIPPINE ${ }^{3}$, \\ FRANCOIS-XAVIER ROBIN ${ }^{3}$ AND EDOUARD METZGER ${ }^{4}$ \\ ${ }^{1}$ LIENSs \\ ${ }^{2}$ Université d'Angers \\ ${ }^{3}$ UNIMA \\ ${ }^{4}$ LPG-BIAF, Université d'Angers \\ Presenting Author: raphael.moncelon1@univ-lr.fr
}

The importance of wetland ecosystems has been widely recognized for ecosystem services such as carbon catchment control or water purification carried out by primary producers. The availability of nutrients constitutes a strong factor for the dynamics of these autotroph organisms, and especially phytoplankton. The physical aspect of freshwater marshes allows a large amount of organic matter to sediment and lead to consider the nutrient exchanges across the sediment-water interface as a key factor for water column biochemical dynamics. However, few studies seem to establish a real link between nutrient regeneration dynamics in the sediment and its impact on phytoplankton development in freshwater marshes. A first follow up was conducted during 2019 in a secondary channel of the artificial marsh of Marans (Charente Maritime, France) mainly dominated by agricultural activities inducing very high exported nitrate contents. Conventional core slicing/centrifugation and 2D DET probes were both applied for geochemical pore water analyses and evaluate the mobilization of remineralization products in the upper centimeters of sediment. It clearly established that benthic denitrification dominated diagenetic processes early winter preventing metal oxides reduction and subsequent phosphorous release towards water column. Benthic nitrate mitigation allowed during early spring the bacteria consortium to reduce iron oxides suppressing phosphate adsorption sites from the "iron curtain" and therefore allowing recycled phosphorous to diffuse towards the water column. These results demonstrate the importance of the sediment as a pool of phosphate for water column in this environment, all the more so since this release seems to have triggered a slight nanophytoplankton bloom. Since 2020, two secondary channels contrasted by adjacent land use are followed. First results seem to show more complex phytoplankton seasonal patterns that will be interpreted under the light of porewater results under acquisition. The strong influence of an anthropised watershed on the redox conditions of the sediment, in particular via nitrate input, seems to control the mobilization of nutrients limiting primary production such as phosphates. Appropriate management of these systems is necessary in order to limit the risks of eutrophication phenomena and impairment of their ecological functions. 